\title{
A Woman of Voice: Mary-Anne Elizabeth Plaatjies-Van Huffel (15 December 1959-19 May 2020)
}

\author{
Reggie W. Nel \\ https://orcid.org/0000-0001-6748-0115 \\ Stellenbosch University, Faculty of Theology, South Africa \\ rwnel@sun.ac.za
}

What an honour to share in a moment of celebration, remembrance, and deep reflection! We present this Festschrift today, at the second Mary-Anne Plaatjies-Van Huffel Memorial Lecture, in the month of August, Women's Month in South Africa, in a season of lament, yet also resilience and compassion as we face a new future. It is our hope that her enduring prophetic genius will again illuminate our paths.

When Professor Mary-Anne Plaatjies-Van Huffel fell ill and passed on during 2020, only a few months before what was to be her historic inaugural professorial lecture on 12 August 2020 as the first Black woman to be promoted to Professor at Stellenbosch University's Faculty of Theology, she was most certainly considered amongst the most respected ecumenical leaders on the African continent at the time and amongst the leading Reformed ecumenical leaders globally. She was African-Reformed. She was also more than that. As we celebrate, remember and reflect on her legacy, and keep on being challenged by it, learning and growing, the question is what this "more than that" would mean for today and tomorrow and where it came from.

Mary-Anne Elizabeth Plaatjies-Van Huffel was rooted and shaped largely in the heart of the spirituality of the former Dutch Reformed Mission Church-the church community that gave birth to the Confession of Belhar, and later, the Uniting Reformed Church in Southern Africa. She however remained open to ecumenical scholarship and fellowship, and therefore continued to grow and also engage her roots critically and compassionately. One cannot speak therefore of "the" spirituality as if there is only one. In her own pastoral and ecumenical leadership she pursued African, Reformed, ecumenical, evangelical, liberatory, feminist and public forms of spirituality, and it was this rich complexity which shaped her contributions to theological and ministerial (trans)formation, focussed towards to what she would call "post-patriarchal" faith communities, rooted in the Confession of Belhar. Indeed, she was also even more than

\section{UNISA $\cong$}


this. The celebratory, appreciative and critical contributions in this Festschrift provide a mere glimpse of the depth of her legacy.

It goes without saying that she also had her detractors. Of course, we are not referring merely to respectful peer review amongst colleagues. She welcomed that. In fact, she participated wholeheartedly, always with her sharp intellect, dignity and poise in robust academic, synodical and ecumenical debates. In some of her last pieces of writing, she however wrestled with the moments of deep disappointment and the ongoing trauma experienced through structures and ecclesial cultures that remained deeply patriarchaldeeply insensitive and violent. Yet she also transcended this-rising above these experiences.

Prof. Plaatjies-Van Huffel continued in her toil in order to overcome oppressive structures in society, church and academia. This she did through leading the worldchurch and in her pastoral care to the vulnerable, but also through her writing and teaching. In the Faculty of Theology at Stellenbosch University, where she taught and published, she often led staff and students in many moments of protest and defiance against gender-based violence and racism; she embodied her scholarship - it was never merely about ego. It was a calling, a necessity.

In an opening reflection in her book, Mouth Full of Blood, Toni Morrison reflects on what she calls "certain kinds of trauma visited on people" (2019, ix), which, she continues,

... are so deep, so cruel, that unlike money, unlike vengeance, even unlike justice, or rights, or the goodwill of others, only writers can translate such trauma and turn sorrow into meaning, sharpening the moral imagination.

A writer's life and work are not a gift to mankind (sic); they are its necessity.

This was the labour of Plaatjies-Van Huffel. She turned sorrow into meaning and sharpened our moral imagination. We drink from her wells and will continue to allow ourselves to be challenged.

To honour someone as a writer does not mean to always agree with that person. We honour our forebears by taking their work seriously and also engaging with it, learning from it and building on it. That is the nature of the different contributions to this Festschrift. The Festschrift is divided into three parts: the first section of articles is on her life and work, the second on the kind of research that she inspired, and the last on various case studies on women and church. We conclude with the challenge, most appropriately, by Prof. Christina Landman, her first doctoral promotor, presented at the historic first Mary-Anne Plaatjies-Van Huffel Memorial Lecture on 12 August 2020.

The first part opens with the article by David Pieter Carelse, who grapples with the question of whether Plaatjies-Van Huffel was merely an academic, or also a grass-roots prophetess. He worked closely with her in church and explores her influential career as 
a feminist theologian in church, society and academia. One of her first doctoral students, who now teaches at the University of Pretoria, Jacques W. Beukes, then relates her work to the current upsurge of racism and how the Belhar Confession can be, what he calls, a beacon of light. Another colleague of hers, Selaelo Thias Kgatla, someone she considered one of her mentors, reflects on the significance of her role in URCSA, being a leader in a "world of hostility and contradiction."

She however did not only make significant contributions within URCSA. Dion Angus Forster, the Chair of the Department of Systematic Theology and Ecclesiology, where she taught, continues to engage her contribution to the interface between religion and law. She worked with Prof. Forster at the Beyers Naudé Centre for Public Theology, leading the Unit for Religion and Law. This is followed by the contribution by two of her students and now colleagues, Ashwin Afrikanus Thyssen and Sheurl Davis, as they explore what they call her "Womanist Public" engagement. This is followed by Tobias Masuku's engagement with Plaatjies-Van Huffel's work on Blackness. Incidentally, in one of her last chapters published in 2020 - she was invited by the dean of Union Theological Seminary to write on the work of the late James Cone-she worked on the notion of Blackness. In her contribution she focussed on Blackness as an ontological symbol. Indeed food for thought! Johan M. van der Merwe reflects on her life and work, while Willie S. Zeze focusses on the silent partners in the Reformed world.

As Prof. Plaatjies-Van Huffel's last doctoral graduate, Nathan Philander appropriately presents her contribution to the writing of church historiography in South Africa. Dr Philander served with Prof. Plaatjies-Van Huffel on the Ministerial Formation ministries in URCSA and they journeyed close together reflecting on and shaping the next generation of faith leaders. Her students were her passion, and she was referred to affectionately as "Ma." It is therefore appropriate that the section on her life and work is concluded with the article by her former dean, Nico N. Koopman, on justice through virtuous leadership and decision making. Her life — and work and embodiment-was indeed her witness towards caring justice.

The second set of articles focusses on research themes that she inspired. One cannot really separate her life and work from the research themes that were close to her heart. However, in this and the third section, one can also identify themes that emerged out of her work and the scholarly community that she was part of. Her colleague in the Department of Systematic Theology and Ecclesiology, Robert Vosloo, focusses on the theme of recognition discourse and systemic gender injustice, while Eugene Baron brings attention to media and reconciliation. Pieter Grove discusses diversity in her church, the Uniting Reformed Church in Southern Africa.

As indicated, the last section brings together research in themes and particular case studies that are currently explored in the discipline that was close to her heart, namely Ecclesiology and Church Polity It addresses issues like race and gender, the ordination of women, cultural practices (also in ministry) that continue to subjugate and 
discriminate against women and their implications for pastoral ministry-also for pastors' wives. These articles, as varied as they might seem, bring together the threads and complexity, but also the wealth of the legacy of the late Prof. Mary-Anne Elizabeth Plaatjies-Van Huffel.

As indicated earlier, it is appropriate that Christina Landman has the "last word" in this Festschrift. Apart from the fact that she was Plaatjies-Van Huffel's promotor, she herself fought against patriarchy, becoming the first woman Professor in Theology at a South African university. In her article she shows why she considers Plaatjies-Van Huffel within Afrikaans Reformed circles to be the first to raise the issues of gender equity and theology at the level of doctoral research - a first ecclesiastical voice on gender equity in South Africa. She discerns what she calls "a theology based on the four Plaatjies-Van Huffel criteria for gender equality," namely, the values of transformation, inclusivity, relationality and holism. While Landman presents her conclusion on whether this was taken up in church and academia, and based on her own journey, draws the same conclusion of Plaatjies-Van Huffel, that she also poses a challenge, a vision perhaps, for deep healing. We all need that - the church, the academy, and our society.

It is with this challenge before us - especially during a global pandemic that gave new meaning to the theology of and our ministries of healing, that we present this Festschrift in honour of the late Rev. Prof. Dr Mary-Anne Elizabeth Plaatjies-Van Huffel.

\section{References}

Morrison, Toni. 2019. Mouth Full of Blood: Essays, Speeches, Meditations. New York: Vintage. 